\title{
Distribution of HCV Genotypes and RNA Viral Load Along with Hemato-Biochemical Analysis of HCV Patients in Rahim Yar Khan, Okara and Toba Tek Singh Districts of Punjab, Pakistan
}

\author{
Suliman Qadir Afridi, ${ }^{1}$ Nasar Khan, ${ }^{2}$ Muhammad Akmal, ${ }^{2}$ Sardar Ali, ${ }^{2}$ Attaullah S., ${ }^{2}$ Sulaiman \\ Bahadar, ${ }^{2}$ Abdul Aziz, ${ }^{2}$ Nasir Ali, ${ }^{3,4,7}$ Firasat Hussain, ${ }^{5}$ Furqan Awan, ${ }^{6}$ and Muhammad Muddassir Ali ${ }^{7,}$ \\ ${ }^{1}$ Department of Microbiology, University of veterinary and animal sciences, Lahore, 54000, Pakistan \\ ${ }^{2}$ Department of Microbiology, Kohat University of Science and Technology, Kohat 26000, Pakistan \\ ${ }^{3}$ Departamento de Engenharia de Bioprocessos e Biotecnologia, Universidade Federal do Paraná (UFPR), Curitiba, Parana, Brazil \\ ${ }^{4}$ Instituto de Biologia Molecular do Paraná (IBMP), FIOCRUZ, Curitiba, Parana, Brazil \\ ${ }^{5}$ Yunnan Institute of Microbiology, school of life sciences, Yunnan university, kuming, China \\ ${ }^{6}$ Department of Epidemiology and Public Health, University of veterinary and animal sciences, Lahore, 54000, Pakistan \\ ${ }^{7}$ Institute of Biochemistry and Biotechnology, University of veterinary and animal sciences, Lahore, 54000, Pakistan \\ "Corresponding author: Muhammad Muddassir Ali, Institute of Biochemistry and Biotechnology, UVAS, Lahore 54000, Pakistan. E-mail: muddassir.ali@uvas.edu.pk
}

Received 2014 October 14; Revised 2015 January 07; Accepted 2017 June 21.

\begin{abstract}
Background: HCV has very diverse genotypes in nature, divided into variable number of subtypes. Due to epidemiologically divergent subtypes, it shows diverse geographical distributions, which makes it difficult to treat. This disease plays havoc with underdeveloped and developing countries due to scarcity of data and poor awareness among common people. Therefore, this study aimed to evaluate the geographical distribution of HCV genotypes and RNA viral load along with hemato-biochemical analysis of HCV patients in underdeveloped and neglected areas of Punjab province, Pakistan.

Results: Out of 1115 samples, 583 (52.3\%) from males and 532 (47.7\%) from females were declared as HCV RNA positive samples. In all the three regions, genotype $3(46.3 \%)$ was found to be the most frequent genotype in both genders followed by genotype 2 (28.9\%), genotype $1(12.5 \%)$, genotype $4(2.2 \%)$, genotype $5(1.8 \%)$, genotype $6(1.2 \%)$, untypeable genotypes (5.2\%), and mixed genotypes (2.41\%). Most of the patients had viral load less than $600,000 \mathrm{IU} / \mathrm{mL}$.

Conclusions: HCV genotype 3a is the most prevalent genotype in various regions of Punjab. Effective HCV awareness programs and novel therapeutic measures should be enforced to combat against HCV infection. Moreover, geographical distribution and mapping of HCV in Pakistan should be studied to develop better control strategies against HCV infection.
\end{abstract}

Keywords: HCV 3a, Punjab, Lahore, Viral Load, Genotype, Molecular Epidemiology

\section{Background}

It is a well-established fact that hepatitis C virus (HCV) is playing havoc worldwide. HCV genotypes are substantially divergent in sequence from each other; they fall into seven phylogenetic clades, designated as genotypes and within these, a variable number of sub-groupings are obvious. HCV variants circulating in Western countries have been designated as subtypes of which, 1a, 1b, 2a, 2b, 3a, 4a, and $6 a$ are the most frequently identified ones (1). HCV subtypes are epidemiologically divergent, with differences in risk group targeting and geographical distributions that reflect their recent epidemic spread (2). The rate of nucleotide sequence change in viruses, particularly in those with RNA genome e.g. HCV, HGV/GBV-C, is invariably much greater than that of their hosts; this presents a number of problems in evolutionary reconstruction. This introduces a significant genome diversity in HCV, which necessi- tates the classification of different strains into major genotypes and their subtypes. Understanding the origin and nature of HCV genetic diversity is critical for defining preventive strategies as well as for development of therapies and vaccine. Phylogenetic methods are essential tools for the study of molecular epidemiology. The confirmatory gold standard and the most definitive method for HCV genotyping is sequencing of a specific PCR-amplified portion of the HCV genome obtained from the patient, followed by phylogenetic analysis $(3,4)$.

Moreover, beside HCV genotypes, hematological, biochemical, and pre-treatment viral load has also been shown to be the prognostic indicator of response to antiviral therapy (5), as increased pre-treatment viral load and very disturbed hemato-biochemical values have been linked with low rates of response to standard interferon therapy (6). In Pakistan, although considerable research has been observed in many districts and cities on the preva-

Copyright (c) 2017, Hepatitis Monthly. This is an open-access article distributed under the terms of the Creative Commons Attribution-NonCommercial 4.0 International License (http://creativecommons.org/licenses/by-nc/4.0/) which permits copy and redistribute the material just in noncommercial usages, provided the original work is properly cited. 
lence of HCV genotypes $(7,8)$, not much data is available regarding the correlation between hemato-biochemical values, viral load, and HCV genotypes. Therefore, the present study emphasizes the distribution of different HCV genotypes, pretreatment hemato-biochemical analysis, and HCV RNA viral load in HCV infected patients in Rahim Yar khan, Okara, and Toba Tek Singh districts of Punjab province, Pakistan, which are most neglected areas of this region.

\section{Methods}

2.1. Sample Collection, Serological and Hemato-Biochemical Analysis

A total 1115 blood samples were collected from the three districts of Rahim Yar Khan $(\mathrm{n}=439)$, Okara $(\mathrm{n}=317)$, and Toba Tek Singh $(n=359)$ in Punjab from the clinically affected patients for one year from 2012 to 2013. According to the inclusion criteria, the study involved only those patients with the clinical signs and results based on ELISA. All the patients with any other hepatitis due to reasons other than hepatitis $\mathrm{C}$ (e.g. autoimmune hepatitis, hemochromatosis, and Wilson's disease) were excluded. Initially, consent was taken from each individual and the study was approved by the ethics committee of the institute. Then, all samples were screened by ELISA followed by Hemato-biochemical analysis (hemoglobin, platelets, TLC, total bilirubin, ALT, ALP, Total proteins, albumin, and globulin) on Hitachi 902 fully automated chemistry analyzer by Roche Diagnostics, Germany.

\subsection{HCV Qualitative and Quantitative Test}

HCV qualitative and quantitative analysis was carried out for all the samples by the method of Ali et al. 2008 (8). All qualitative PCR positive samples were further subjected for HCV genotyping by the protocol carried by Afridi et al. 2014 (9). Serum from each blood sample was separated at $3000 \mathrm{~g}$, tagged, and kept at $-20^{\circ} \mathrm{C}$ until further processing. RNA extraction was carried out using Qiagen kit (Invitrogen, Corp., California; USA) as per manufacturer's instruction. Complimentary DNA (cDNA) was synthesized using Invitrogen kit as per manufacturer's guideline. The final PCR product gained either after qualitative or genotypespecific PCR was further processed to electrophoresis in $2 \%$ agarose gel containing ethidium bromide along with 100bp DNA ladder(Invitrogen, Corp., California; USA). The photographs of banding pattern, was taken by Gel Doc System to check genotype specific bands.

\subsection{Statistical Analysis}

Statistical analysis was done by using SPSS version 16.0 software. Student t-test and Chi-square tests were performed to analyze differences in continuous and categorical data, respectively. P value $<0.05$ was considered as significant. Multiple regression analysis was used to evaluate independent associations between HCV genotypes, individual demographic characteristics, and biochemical values to identify variables association within different genotypes.

\section{Results}

The prevalence of different HCV genotypes and viral load among both genders in different geographical regions of Punjab province is shown in Figure 1 and Table 1. Of 1115 samples, 583 (52.3\%) from males and 532 (47.7\%) from females were declared as HCV positive that showed nearly equal representation in both genders (Figure 2). Among these 1115 samples, 1057 (94.8\%) were detected based on specific PCR fragment while 58 (5.2\%) remained unable to demonstrate a specific genotypic band. Genotype 3 (46.3\%) was the most frequent one in both genders followed by genotype $2(28.9 \%)$, genotype $1(12.5 \%)$, genotype $4(2.2 \%)$, genotype $5(1.8 \%)$, genotype $6(1.2 \%)$, and untypeable genotypes (5.2\%) (Figure 1). Among the sub-genotypes, the most detected sub-genotype in males was 3a subtype (42.20\%) followed by 2 a subtype (24.53\%) and 1a subtype (7.89\%). Other less frequent subtypes were $2 \mathrm{~b}(2.49 \%), 3 \mathrm{~b}(3.77 \%), 1 \mathrm{~b}$ (3.6\%), 1c (1.03\%), 4 (1.54\%), 5a (1.54\%), 6a (1.20\%), and mixed (2.4\%). In females, the most frequent sub-genotypes were 3a (41.92\%), 2a (24.06\%), 1b (5.26\%), 3b (4.70\%), 1c (0.56\%), 4 (3.01\%), 6a (1.13\%), mixed (1.4\%), and $2 \mathrm{~b}$ (4.89\%) (Figure 1).

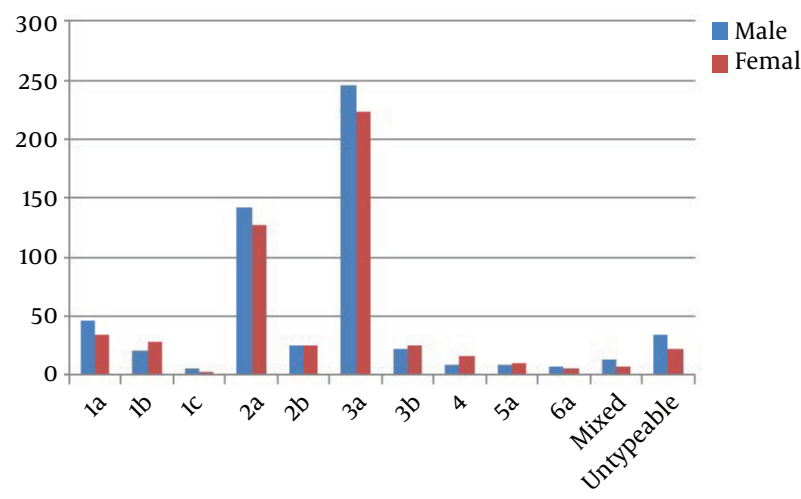

Figure 1. Prevalence of HCV Genotypes in Both Genders

Based on age, different groups of genotyped samples were formed such as 10 - 20 years, 21 - 30 years, 31 - 40 years, 


\begin{tabular}{|c|c|c|c|c|}
\hline \multirow[t]{2}{*}{ Genotype/Subtype } & \multicolumn{3}{|c|}{ Viral Load } & \multirow[t]{2}{*}{ P Value } \\
\hline & $<600,000$ & $600,000-800,000$ & $>800,000$ & \\
\hline Genotype 3 & 170 & 196 & 150 & \multirow{2}{*}{0.937} \\
\hline Other genotypes & 194 & 225 & 180 & \\
\hline Male & 186 & 239 & 158 & \multirow{2}{*}{0.065} \\
\hline Female & 188 & 182 & 162 & \\
\hline \multicolumn{4}{|l|}{ Toba Tek Singh } & \multirow{3}{*}{0.301} \\
\hline Genotype 3 & 53 & 47 & 51 & \\
\hline Other genotypes & 74 & 78 & 56 & \\
\hline \multicolumn{4}{|l|}{ Okara } & \multirow{3}{*}{0.454} \\
\hline Genotype 3 & 37 & 63 & 37 & \\
\hline Other & 60 & 73 & 47 & \\
\hline \multicolumn{4}{|l|}{ Rahim Yar Khan } & \multirow{3}{*}{0.475} \\
\hline Genotype 3 & 59 & 72 & 50 & \\
\hline Other & 91 & 88 & 79 & \\
\hline
\end{tabular}

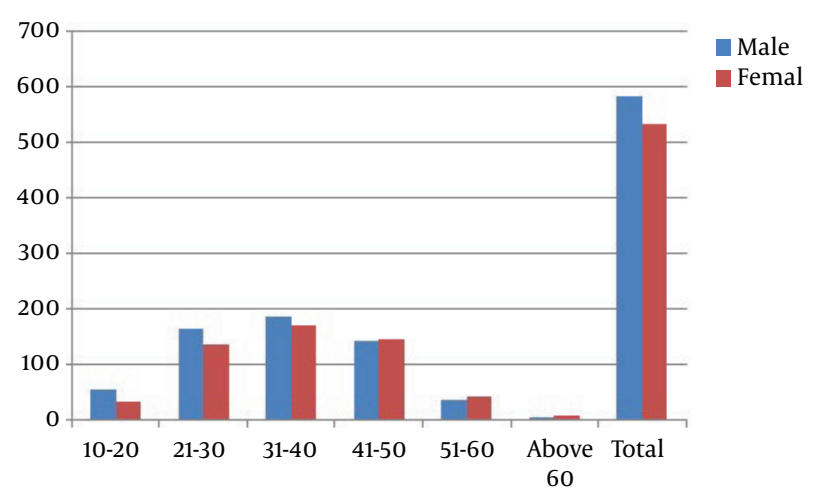

Figure 2. Prevalence of HCV among Different Age Groups in Both Genders

41 - 50 years, 51 - 60 years, and above 60 years. The overall percentage of positive HCV samples in all the age groups was higher in males than females except for the age group 41 - 50 years, 51 - 60 years, and above 60 years (Figure 2 ). The distribution of genotypes in all the age group categories was also observed. Genotype 3a was highest in all the age groups (42.1\%) followed by genotypes $2 \mathrm{a}(24.3 \%), 1 \mathrm{a}(7.3 \%), 2 \mathrm{~b}$ (4.6\%), $1 \mathrm{~b}(4.4 \%), 3 \mathrm{~b}(4.2 \%), 4$ (2.2\%), 5a (1.8\%), 6a (1.2\%), and mixed genotypes (2.0\%). On the other hand, the age group 31 - 40 years had the highest frequency of cases while the lowest frequency was observed in the age group of above 60 years (Table 2 ).

Among the total HCV positive samples, the highest frequency of HCV positive patients was observed in Rahim
Yar Khan with 439 (39.4\%) positive cases, followed by 359 (32.2\%) that belonged to Toba Tek Singh while the lowest frequency was observed in Okara district with 317 (28.4\%) positive samples. Among all the districts, 3a had the highest frequency and 1c had the lowest frequency (Table 3).

Viral load was categorized into three classes according to the specified levels as low level $(<60,0000 \mathrm{IU} / \mathrm{ml})$, intermediate level (60,0000 - 80,0000 IU/mL), and high level ( $>$ $80,0000 \mathrm{IU} / \mathrm{mL}$ ) viral loads. No significant differences were detected in HCV infected patients of both genders (Table 1). The viral load with respect to genotypes based on districts and genders was determined as shown in Table 1.

Along with the viral load, clinical profile of the patients was also recorded. The clinical profile included different blood parameters, levels of different liver enzymes, and levels of albumin and globulin as given in Table 4 .

\section{Discussion}

The current study demonstrated the frequency of various HCV genotypes in different categories and their association with demographic and biochemical parameters. This study ascertained that HCV genotypes were spread with equal probability between the both sexes and there was no association between gender and HCV genotypes. These results are in agreement with multiple previous studies indicating little statistical association between genders and genotypes in Pakistan (8, 10-12). This study contradicts a Libyan study that showed the association of various HCV genotypes with gender (13). 
Table 2. Distribution of HCV Genotypes Among Different Age Groups ${ }^{a}$

\begin{tabular}{|c|c|c|c|c|c|c|}
\hline \multirow[t]{2}{*}{ Genotype } & \multicolumn{6}{|c|}{ Age Group } \\
\hline & $10-20$ & $21-30$ & $31-40$ & $41-50$ & $51-60$ & Above 60 \\
\hline $\mathbf{1 a}$ & $4(4.60)$ & $21(7.00)$ & $23(6.46)$ & $25(8.77)$ & $8(10.26)$ & $0(0)$ \\
\hline $\mathbf{1 b}$ & $5(5.75)$ & $9(3.00)$ & $20(5.62)$ & $13(4.56)$ & $2(2.56)$ & $0(0)$ \\
\hline 1c & $2(2.30)$ & $3(1.00)$ & $4(1.12)$ & $0(0)$ & $0(0)$ & $0(0)$ \\
\hline $\mathbf{2 a}$ & $19(21.84)$ & $71(23.67)$ & $89(25)$ & $66(23.16)$ & $23(29.49)$ & $3(33.33)$ \\
\hline $2 \mathbf{b}$ & $5(5.75)$ & $10(3.33)$ & $20(5.62)$ & $13(4.56)$ & $2(2.56)$ & $1(11.11)$ \\
\hline $3 a$ & $39(44.83)$ & $142(47.33)$ & $136(38.20)$ & $116(40.70)$ & $33(42.31)$ & $3(33.33)$ \\
\hline $3 \mathbf{b}$ & $6(6.90)$ & $14(4.67)$ & $15(4.21)$ & $7(2.46)$ & $5(6.41)$ & $0(0)$ \\
\hline 4 & $2(2.30)$ & $5(1.67)$ & $7(1.97)$ & $10(3.51)$ & $0(0)$ & $1(11.11)$ \\
\hline $5 a$ & $2(2.30)$ & $2(0.67)$ & $9(2.53)$ & $6(2.11)$ & $1(1.28)$ & $0(0)$ \\
\hline $6 \mathbf{a}$ & $0(0)$ & $3(1)$ & $7(1.97)$ & $2(0.70)$ & $1(1.28)$ & $0(0)$ \\
\hline Mixed & $2(2.29)$ & $6(2)$ & $6(1.68)$ & $7(2.45)$ & $1(1.28)$ & $0(0)$ \\
\hline Untypeable & $1(1.15)$ & $14(4.67)$ & $20(5.62)$ & $20(7.02)$ & $2(2.56)$ & $1(11.11)$ \\
\hline Total & 87 & 300 & 356 & 285 & 78 & 9 \\
\hline
\end{tabular}

${ }^{\mathrm{a}}$ Values are expressed as No. (\%).

Table 3. Distribution of HCV Genotypes Among Different Districts ${ }^{\mathrm{a}}$

\begin{tabular}{cccc}
\hline \multirow{2}{*}{ Genotype } & \multicolumn{3}{c}{ Districts } \\
\cline { 2 - 4 } & Toba Tek Singh & Rahim Yar Khan & Okara \\
\hline 1a & $27(7.52)$ & $34(7.74)$ & $20(6.31)$ \\
\hline 1C & $14(3.90)$ & $22(5.01)$ & $13(4.10)$ \\
\hline 2a & $4(1.11)$ & $2(0.46)$ & $3(0.95)$ \\
\hline 2b & $89(24.79)$ & $111(25.28)$ & $71(22.40)$ \\
\hline 3a & $13(3.62)$ & $19(4.33)$ & $19(5.99)$ \\
\hline 3b & $151(42.06)$ & $181(41.23)$ & $137(43.22)$ \\
\hline 4 & $19(5.29)$ & $15(3.42)$ & $13(4.10)$ \\
\hline 5a & $12(3.34)$ & $8(1.82)$ & $5(1.58)$ \\
\hline 6a & $5(1.39)$ & $8(1.82)$ & $7(2.21)$ \\
\hline Mixed & $4(1.11)$ & $5(1.14)$ & $4(1.26)$ \\
\hline Untypeable & $8(2.23)$ & $8(1.82)$ & $6(1.89)$ \\
\hline Total & $13(3.62)$ & $26(5.92)$ & $19(5.99)$ \\
\hline a & $359(32.30)$ & $439(39.37)$ & $317(28.43)$ \\
\hline
\end{tabular}

${ }^{\mathrm{a}}$ Values are expressed as No. (\%).

Regarding age groups, a high prevalence of HCV infection was found to occur below the age of 50 years. The former studies noted a higher prevalence in age group of $\leq$ 40 years that is in partial agreement with the current findings. It has also been found that $\mathrm{HCV}$ infection was higher among females with the age above 40 years as compared to males with the same age.

It has been well-established that HCV genotype $3 \mathrm{a}$ is highly prevalent in Pakistani population $(9,11,14)$. On the other hand, a single study revealed that 1a genotype has a higher frequency in Balochistan (7). This study inferred that HCV genotype 3a is the most frequent genotype in Pakistan $(7,11)$. The distribution of HCV genotypes is close to the documented studies from other South Asian countries where genotype 3 is more frequent than other genotypes (15). This study also reported many rare genotypes like 5a, $1 c$, and 6a, which are uncommon and less reported. Unlike Ali et al. (8) sudy findings, the findings of this study support the verdict of some previous studies that showed the presence of genotypes such as 5a, $4 \mathrm{a}$, and $1 \mathrm{c}$ in spite of their rare status $(9-11,16)$. These findings are in contradiction with those of some studies that have shown the partial absence of genotypes 4,5 , and $6(8,17)$.

Moreover, this study also documented the mixed genotype infections. To the author's knowledge, mixed genotypes like $1 b+4,2 a+5 a$, and $3 a+5 a$ were not reported before in Pakistan. Although the frequency of mixed genotypes was very low in this study, such pattern of coinfections can pose problems in therapeutic regimes (18).

In this study, HCV RNA titre was also determined with respect to genotypes in different districts and genders as shown in Table 1. As determined in the past studies, HCV RNA titer was categorized into three levels based on their 
Table 4. Different Clinical Parameters Along with Acceptable Normal Values

\begin{tabular}{|c|c|c|c|c|}
\hline Clinical Parameters & Normal Values & Minimum & Maximum & Mean \pm Std. Deviation \\
\hline Haemoglobin Level, g/dL & $11-18$ & 8.10 & 17.80 & $13.59 \pm 1.61$ \\
\hline TLC Level, ${ }^{*} 10^{3} / \mathrm{mm}^{3}$ & $4-11$ & 2.70 & 27.40 & $9.71 \pm 3.48$ \\
\hline Platelet Count, ${ }^{*} 10^{3} / \mathrm{mm}^{3}$ & $150-400$ & 7.70 & 389.00 & $274.02 \pm 51.80$ \\
\hline Total Bilirubin, mg/dL & 1 & 0.30 & 4.40 & $1.31 \pm 0.65$ \\
\hline ALT & $<45$ & 21.00 & 978.00 & $71.46 \pm 98.02$ \\
\hline ALP & $<258$ & 106.00 & 735.00 & $242.11 \pm 72.27$ \\
\hline Total Protein, g/dL & $6.6-8.8$ & 4.20 & 8.70 & $7.58 \pm 0.72$ \\
\hline Albumin, $\mathbf{g} / \mathbf{d L}$ & $3.8-5.1$ & 1.90 & 5.20 & $4.39 \pm 0.63$ \\
\hline Globulin, $\mathbf{g} / \mathbf{d L}$ & $2.3-3.8$ & 2.10 & 3.90 & $3.19 \pm 0.27$ \\
\hline Albumin Globulin Ratio & $1.2-2.2$ & 0.60 & 2.30 & $1.37 \pm 0.22$ \\
\hline ELISA & 1 & 0.29 & 65.40 & $6.73 \pm 5.51$ \\
\hline
\end{tabular}

specified values as low level $(<600,000 \mathrm{IU} / \mathrm{mL})$, intermediate level (600,000 - 800,000 IU/mL), and high level ( $>$ $800,000 \mathrm{IU} / \mathrm{mL}$ ) (8). Genotype $3 \mathrm{HCV}$-infected patients falling in the low level RNA titer category i.e. low level $(<$ $600,000 \mathrm{IU} / \mathrm{mL}$ ) usually get shorter therapy and quickly attain early viral response (EVR) and Sustained Viral Response (SVR) as compared to other categories specially the category of high level $(>800,000 \mathrm{IU} / \mathrm{mL})(9,19,20)$. In the current study, about 150 patients from genotype 3 belonged to the low-level RNA titer category, likely to gain undetectable viral load in a 4 to 8-week duration. For the other two categories, the protocols of 16 weeks and 24 weeks are likely to be followed $(8,19,20)$. In line with previous studies, this study also emphasizes the need of prior information regarding RNA titer while formulating the therapy protocols including protocols of 16 weeks and 24 weeks ( 8 , $9,21)$.

In contrast to most previous studies conducted in Pakistan, this study also reported the clinical profile of HCV patients (22). This study could be used as an evident document in providing information about clinical profile of HCV patients. Moreover, the current study has also tried to correlate the enzyme profile with genotypes recorded. In the former studies, genotypes have not found to be correlated with enzyme profile of the patients $(4,23,24)$. Possibly, due to less sample size, regression model and correlation could not provide any statistical significance, which is in contrast to recent studies (16).

\section{Footnotes}

Authors' Contribution: This study is a result of collective work. Suliman Qadir Afridi and Nasar Khan contributed equally in the study. Suliman Qadir Afridi, Nasar Khan, and Muhammad Muddassir Ali conceived the study and participated in its design. Muhammad Akmal, Sardar Ali, and Nasir Ali contributed to the sample collection. Attaullah, Sulaiman Bahadar, Abdul Aziz and Firasat Hussain conducted the serological tests, hemato-biochemical analysis, and HCV qualitative and quantitative tests. Furqan Awan carried out the statistical analysis. Muhammad Muddassir Ali drafted the manuscript. Suliman Qadir Afridi and Furqan Awan participated in the discussion and modification of the manuscript. All authors read and approved the final manuscript.

Competing Interests: The authors declare that they have no competing interests.

Financial Disclosure: This project was not funded by any agency.

\section{References}

1. Simmonds P, Bukh J, Combet C, Deleage G, Enomoto N, Feinstone $\mathrm{S}$, et al. Consensus proposals for a unified system of nomenclature of hepatitis C virus genotypes. Hepatology. 2005;42(4):962-73. doi: 10.1002/hep.20819. [PubMed: 16149085].

2. Nelson PK, Mathers BM, Cowie B, Hagan H, Des Jarlais D, Horyniak D, et al. Global epidemiology of hepatitis B and hepatitis $C$ in people who inject drugs: results of systematic reviews. Lancet. 2011;378(9791):57183. doi: 10.1016/S0140-6736(11)61097-0. [PubMed: 21802134].

3. Bukh J, Miller RH, Purcell RH. Genetic heterogeneity of hepatitis C virus: quasispecies and genotypes. Semin Liver Dis. 1995;15(1):41-63. doi: 10.1055/s-2007-1007262. [PubMed: 7597443].

4. Simmonds P. Variability of hepatitis C virus. Hepatology. 1995;21(2):570-83. [PubMed: 7531173].

5. Yoshioka K, Kakumu S, Wakita T, Ishikawa T, Itoh Y, Takayanagi M, et al. Detection of hepatitis $C$ virus by polymerase chain reaction and response to interferon-alpha therapy: relationship to genotypes of hepatitis C virus. Hepatology. 1992;16(2):293-9. [PubMed: 1322348]. 
6. Martinot-Peignoux M, Marcellin P, Pouteau M, Castelnau C, Boyer N, Poliquin $\mathrm{M}$, et al. Pretreatment serum hepatitis $\mathrm{C}$ virus RNA levels and hepatitis $C$ virus genotype are the main and independent prognostic factors of sustained response to interferon alfa therapy in chronic hepatitis C. Hepatology. 1995;22(4 Pt1):1050-6. [PubMed: 7557850].

7. Idrees $M$, Riazuddin S. Frequency distribution of hepatitis $C$ virus genotypes in different geographical regions of Pakistan and their possible routes of transmission. BMC Infect Dis. 2008;8:69. doi: 10.1186/1471-2334-8-69. [PubMed: 18498666].

8. Ali A, Nisar M, Ahmad H, Saif N, Idrees M, Bajwa MA. Determination of HCV genotypes and viral loads in chronic HCV infected patients of Hazara Pakistan. Virol J. 2011;8:466. doi: 10.1186/1743-422X-8-466. [PubMed: 21982599].

9. Afridi SQ, Ali MM, Awan F, Zahid MN, Afridi IQ, Afridi SQ, et al. Molecular epidemiology and viral load of HCV in different regions of Punjab, Pakistan. Virol J. 2014;11:24. doi: 10.1186/1743-422X-11-24. [PubMed: 24512668].

10. Afridi SQ, Zahid MN, Shabbir MZ, Hussain Z, Mukhtar N, Tipu MY, et al. Prevalence of HCV genotypes in district Mardan. Virol J. 2013;10:90. doi: 10.1186/1743-422X-10-90. [PubMed: 23514695].

11. Attaullah S, Khan S, Ali I. Hepatitis C virus genotypes in Pakistan: a systemic review. Virol J. 2011;8:433. doi: 10.1186/1743-422X-8-433. [PubMed: 21902822].

12. Raja NS, Janjua KA. Epidemiology of hepatitis $C$ virus infection in Pakistan.J Microbiol Immunol Infect. 2008;41(1):4-8. [PubMed: 18327420].

13. Elasifer HA, Agnnyia YM, Al-Alagi BA, Daw MA. Epidemiological manifestations of hepatitis $C$ virus genotypes and its association with potential risk factors among Libyan patients. Virol J. 2010;7:317. doi: 10.1186/1743-422X-7-317. [PubMed: 21073743].

14. Ahmad W, Ijaz B, Javed FT, Jahan S, Shahid I, Khan FM, et al. HCV genotype distribution and possible transmission risks in Lahore, Pakistan. World J Gastroenterol. 2010;16(34):4321-8. [PubMed: 20818816].

15. Chowdhury A, Santra A, Chaudhuri S, Dhali GK, Chaudhuri S, Maity SG, et al. Hepatitis $C$ virus infection in the general population: a community-based study in West Bengal, India. Hepatology. 2003;37(4):802-9. doi: 10.1053/jhep.2003.50157. [PubMed: 12668973].
16. Ahmad W, Ijaz B, Javed FT, Kausar H, Sarwar MT, Gull S, et al HCV genotype-specific correlation with serum markers: higher predictability for genotype 4a. Virol J. 2011;8:293. doi:10.1186/1743-422X-8293. [PubMed: 21663629].

17. Sievert W, Altraif I, Razavi HA, Abdo A, Ahmed EA, Alomair A, et al A systematic review of hepatitis $C$ virus epidemiology in Asia, Australia and Egypt. Liver Int. 2011;31 Suppl 2:61-80. doi: 10.1111/j.14783231.2011.02540.x. [PubMed: 21651703].

18. Butt S, Idrees M, Shahid M, Amin I, Younas S, Afzal S, et al. Change in hepatitis $C$ virus clades: a cross-sectional study of chronic HCV patients in Pakistan from 2000-2010. Eur J Clin Microbiol Infect Dis. 2011;30(5):669-72. doi: 10.1007/s10096-010-1138-1. [PubMed: 21210169].

19. Dalgard O, Bjoro K, Hellum KB, Myrvang B, Ritland S, Skaug K, et al. Treatment with pegylated interferon and ribavarin in HCV infection with genotype 2 or 3 for 14 weeks: a pilot study. Hepatology. 2004;40(6):1260-5. doi: 10.1002/hep.20467. [PubMed: 15558712].

20. von Wagner M, Huber M, Berg T, Hinrichsen H, Rasenack J, Heintges T, et al. Peginterferon-alpha-2a (40KD) and ribavirin for 16 or 24 weeks in patients with genotype 2 or 3 chronic hepatitis C. Gastroenterology. 2005;129(2):522-7. doi: 10.1016/j.gastro.2005.05.008. [PubMed 16083709].

21. Jimenez-Mendez R, Uribe-Salas F, Lopez-Guillen P, Cisneros-Garza L, Castaneda-Hernandez G. Distribution of HCV genotypes and HCVRNA viral load in different regions of Mexico. Ann Hepatol. 2010;9(1):33-9. [PubMed: 20308720].

22. Pratt DS, Kaplan MM. Evaluation of abnormal liver-enzyme results in asymptomatic patients. $N$ Engl J Med. 2000;342(17):1266-71. doi: 10.1056/NEJM200004273421707. [PubMed: 10781624].

23. Tsukiyama-Kohara K, lizuka N, Kohara M, Nomoto A. Internal ribosome entry site within hepatitis C virus RNA.J Virol. 1992;66(3):147683. [PubMed: 1310759].

24. Romeo R, Colombo M, Rumi M, Soffredini R, Del Ninno E, Donato MF, et al. Lack of association between type of hepatitis $C$ virus, serum load and severity of liver disease. J Viral Hepat. 1996;3(4):183-90. [PubMed: 8871879]. 